\title{
Calcium Interference with Zoospore Biology and Infectivity of Phytophthora parasitica in Nutrient Irrigation Solutions
}

\author{
Sharon L. von Broembsen and J. W. Deacon
}

First author: Department of Plant Pathology, Oklahoma State University, 110 Noble Research Center, Stillwater 74078-3032; and second author: Institute of Cell and Molecular Biology, University of Edinburgh, Daniel Rutherford Building, Mayfield Road, Edinburgh EH9 3JH, United Kingdom.

Accepted for publication 3 February 1997.

\begin{abstract}
von Broembsen, S. L., and Deacon, J. W. 1997. Calcium interference with zoospore biology and infectivity of Phytophthora parasitica in nutrient irrigation solutions. Phytopathology 87:522-528.

Calcium, applied as either $\mathrm{CaCl}_{2}$ or $\mathrm{Ca}\left(\mathrm{NO}_{3}\right)_{2}$ to water or calcium-free soluble fertilizer solution (Peters 20-10-20 Peat Lite Special), affected several important stages of Phytophthora parasitica zoospore behavior relevant to infection and disease spread. Release of zoospores from sporangia was suppressed by $\mathrm{Ca}^{2+}$ concentrations in the range of 10 to 50 meq. These concentrations also curtailed zoospore motility; 20 meq of

the release of a single zoospore (diplanetism) from cysts that did not germinate. In growth chamber experiments, the amendment of the fertilizer solution with 10 or $20 \mathrm{mM} \mathrm{Ca}\left(\mathrm{NO}_{3}\right)_{2}$ greatly suppressed infection of flood-irrigated, containerized vinca seedlings in a peat-based mix by motile or encysted zoospores of $P$. parasitica. These results demonstrate that $\mathrm{Ca}^{2+}$ amendments interfere with $P$. parasitica zoospore biology at multiple stages, with compounding effects on epidemiology, and suggest that manipulation of $\mathrm{Ca}^{2+}$ levels in irrigation water or fertilizer solutions could contribute to management of Phytophthora in recirculating irrigation systems.
\end{abstract} $\mathrm{Ca}^{2+}$ in fertilizer solution caused all zoospores to encyst within $4 \mathrm{~h}$, whereas $94 \%$ of zoospores remained motile in unamended solution. In addition, $\mathrm{Ca}^{2+}$ in the range of 10 to 30 meq stimulated zoospore cysts to germinate in the absence of an organic nutrient trigger, while suppressing
Additional keywords: disease management, flood irrigation, greenhouse recirculating systems, oomycota.
Phytophthora, Pythium, and Aphanomyces species (Oomycota) are among the most damaging pathogens of plants in wet soils and irrigated cropping systems. These polycyclic pathogens can destroy plant tissues within a few days and then produce motile zoospores to initiate further cycles of disease. Although direct evidence for a role of zoospores in the infection process has been difficult to obtain in soil, there is increasing recognition that these propagules are important for epidemic development of Phytophthora root rots in crop production $(10,23,29)$, and zoospores have been demonstrated to be the major agents for spread of both Pythium aphanidermatum and Phytophthora capsici in recirculating nutrient systems in greenhouses $(27,28)$. Zoospores locate the most susceptible sites on roots by chemotaxis $(6,18,35)$ and other mechanisms $(22,30)$. This maximizes the chance of infection from individual spores and increases the inoculum potential when zoospores aggregate at infection sites (26). Zoospores also are transported more readily by bulk water flow through soil and other particulate materials than are nonmotile cells (33), and they can penetrate root mats in nutrient films (16). Thus, zoospores also facilitate spread of infection from primary disease foci.

Current control methods for the zoosporic oomycota center mainly on the use of fungicides, but pathogens have developed tolerance to some of these compounds and few fungicides are registered for use in irrigated greenhouse systems. An alternative and more durable approach to disease management would be to interfere with zoospore production or zoospore behavior. This has been achieved experimentally by manipulating the electrical con-

Corresponding author: S. L. von Broembsen

E-mail address: svonbro@okway.okstate.edu

Publication no. P-1997-0305-01R

(C) 1997 The American Phytopathological Society ductivity of nutrient irrigation solutions (29), using surfactants that lyse zoospores $(27,28)$, and applying biocontrol bacteria that reduce zoospore taxis to roots (36) or that alter the ionic composition of media, causing zoospore lysis (11). We have explored a different approach based on the central role of intracellular and extracellular calcium in many aspects of growth and differentiation of the Oomycota (6).

At least a minimum level of extracellular calcium is necessary for production of zoosporangia by Phytophthora spp. (14), for normal motility of Pythium zoospores (9), for adhesion of Pythium and Phytophthora zoospore cysts to host or other surfaces $(8,13)$, and for germination of Pythium (8), Phytophthora (32), and Aphanomyces (J. W. Deacon, unpublished data) zoospore cysts. These effects were demonstrated by direct manipulation of calcium levels, using calcium chelators, or using pharmacological agents known to interfere with calcium-mediated processes in other organisms (9). However, high levels of extracellular calcium can rapidly immobilize Phytophthora zoospores (2), induce zoospore cysts to germinate without a host or nutrient trigger $(2,6)$, and suppress the production of a further zoospore (diplanetism) from a zoospore that encysts when it fails to locate a host (32). High soil calcium levels have also been associated with suppression of disease by several zoospore-forming pathogens $(1,17,19,20,25)$, although the mechanisms of suppression are poorly characterized. They are reported to involve, inter alia, germination of sporangia of Pythium splendens (19), enhanced soil microbial numbers and soil fungistasis $(1,19)$, and enhancement of host plant resistance to several pathogens $(19,20)$.

As part of our goal to understand the role of calcium in zoospore biology and exploit it for disease management, we have studied the effects of calcium amendments on Phytophthora parasitica Dastur in aqueous solutions and in Peters 20-10-20 Peat Lite Special soluble fertilizer solution (Scotts-Sierra Horticultural Prod- 
ucts Company, Marysville, $\mathrm{OH}$ ), which is commonly used in irrigated greenhouse production units in the United States. Here we show that calcium amendments interfere with zoospore biology at multiple stages, which should have compounding effects in epidemiology, and that calcium amendment of irrigation solutions can suppress infection by zoospores significantly.

\section{MATERIALS AND METHODS}

Fungal culture and sporangium production. The isolate of Phytophthora parasitica (= P. nicotianae Breda de Haan) used in these studies originated from diseased vinca (Catharanthus roseus (L.) G. Don) in a commercial greenhouse in Oklahoma. The methods for culture and production of sporangia were as described previously (32), but with the following modification. Small (60 $\mathrm{mm}$ ) petri dishes containing $3 \mathrm{ml}$ of clarified V8 broth were inoculated with three agar inoculum blocks and incubated for $24 \mathrm{~h}$ at $27^{\circ} \mathrm{C}$ to produce mycelial mats. The mats were then rinsed thoroughly with mineral salts solution and reincubated in $3 \mathrm{ml}$ of mineral salts solution for 4 to 5 days beneath fluorescent lights to induce formation of sporangia.

Effects of calcium and fertilizer solutions on zoospore release from sporangia. Sporangium-bearing mycelial mats were rinsed thoroughly with sterile distilled water (SDW), and then 4 $\mathrm{ml}$ of different experimental "release solutions" were added to each dish. Synchronous cleavage of the sporangium contents into zoospores was induced by chilling at $12^{\circ} \mathrm{C}$ for $30 \mathrm{~min}$; the dishes were then removed to room temperature $\left(20\right.$ to $\left.21^{\circ} \mathrm{C}\right)$ and zoospores were released within 1 to $2 \mathrm{~h}$. The release solutions in different experiments included SDW, aqueous 10 to $50 \mathrm{mM} \mathrm{CaCl}_{2}$ or $\mathrm{Ca}\left(\mathrm{NO}_{3}\right)_{2}$ solutions, Peters 20-10-20 Peat Lite Special soluble fertilizer (Peters PLS) at 100 to $450 \mathrm{ppm}$ of N, and Peters PLS at 150 ppm of $\mathrm{N}$ amended with 10 to $50 \mathrm{mM} \mathrm{CaCl} 2$ or $\mathrm{Ca}\left(\mathrm{NO}_{3}\right)_{2}$. Peters PLS contains N, P, and K plus essential micronutrients, but no calcium; solutions of 150,300 , and $450 \mathrm{ppm}$ of $\mathrm{N}$ are equivalent to electrical conductivities (ECs) of 1,2 , and $3 \mathrm{mS} / \mathrm{cm}$. Addition of calcium to Peters PLS in the ranges tested did not measurably affect $\mathrm{pH}$ or EC.

The sporangia on the mycelial mats were examined in situ by mounting a petri dish on a Nikon Labophot research microscope

TABLE 1. Effects of aqueous solutions of $\mathrm{CaCl}_{2}$ on cytoplasmic cleavage in sporangia and on discharge of motile cells from the cleaved sporangia ${ }^{\mathrm{a}}$

\begin{tabular}{lcccccrcc}
\hline & \multicolumn{9}{c}{ Calcium concentration $(\mathrm{mM})$} & & $P$ \\
\cline { 3 - 6 } Sporangia & 0 & 10 & 20 & 35 & 50 & 5\% LSD & (ANOVA) \\
\hline Cleaved & & & & & & & \\
$\quad$ Discharged & 73 & 68.3 & 50 & 35.7 & 33 & 12.94 & $9.5 \times 10^{-5}$ \\
$\quad$ Not discharged & 0 & 8 & 26 & 45.7 & 63 & 11.78 & $1.6 \times 10^{-6}$ \\
Uncleaved & 27 & 23.7 & 24 & 18.7 & 4 & 9.16 & $1.7 \times 10^{-3}$ \\
\hline
\end{tabular}

a Numbers of sporangia (out of 100 assessed); means of counts in three replicate dishes at $2 \mathrm{~h}$ after a 30-min chill induction of sporangial cleavage. with a $10 \times$ objective (Nikon, Inc., Melville, NY). The dishes were scanned using a Sony DXC-151A PAC video camera connected to a Sony SVO 1610 VHS video recorder and a Sony PVM2030 Triniton monitor (Sony Corp. of America, Park Ridge, NJ). The number of sporangia out of 100 that had discharged their contents or that contained cleaved cytoplasm but were not discharged were determined from videotapes of random microscope fields recorded 1 to $3 \mathrm{~h}$ after the chilling treatment. Numbers of zoospores released into solutions at 1 to $2 \mathrm{~h}$ after chilling were determined by transferring 1-ml aliquots of release solution to Eppendorf tubes, encysting the zoospores by vortexing (70 s), and then counting them with a hemacytometer.

Effects of calcium in fertilizer solutions on zoospore motility. Zoospores were released as described above into Peters PLS solution (150 ppm of $\mathrm{N}$ ) amended with $0,10,20,30$, or $40 \mathrm{mM}$ $\mathrm{Ca}\left(\mathrm{NO}_{3}\right)_{2}$. The dishes were examined using the videotaping system at 2.5 to $3.5 \mathrm{~h}$ after chill induction of zoospore release. Both spores at the upper surface of release solutions and spores near the bottoms of dishes were recorded in three random microscope fields per dish. For assessing the time course of motility, the mycelial mats were removed from dishes at $1 \mathrm{~h}$ after chill induction to eliminate any additional release of zoospores. The spores near the upper surfaces of release solutions in three microscope fields per dish were recorded at 1, 2, 3, and $4 \mathrm{~h}$ after induction. Motility was assessed from videotape recordings by circling images of cells on plastic wrap overlaying the monitor while the tape was paused and then advancing the tape by frames to determine which cells were motile. Numbers of motile cells and total cells were counted for each field.

Effects of calcium and fertilizer solutions on cyst germination. Zoospores were released as described above into aqueous solutions of 0,10 , or $20 \mathrm{mM} \mathrm{CaCl} 2$ or into Peters PLS (150 ppm of $\mathrm{N}$ ) amended with 0,10 , or $20 \mathrm{mM} \mathrm{Ca}\left(\mathrm{NO}_{3}\right)_{2}$ or $\mathrm{CaCl}_{2}$. At 1.5 to $2 \mathrm{~h}$ after the chilling of sporangia, zoospores in 1-ml aliquots of release solutions were transferred to Eppendorf tubes, vortex-encysted as described above, and incubated at room temperature for $2 \mathrm{~h}$. The Eppendorf tubes were then vortexed for $10 \mathrm{~s}$ to resuspend cells, and 80- $\mu$ l aliquots were transferred to slides. Germination was assessed by scoring 100 cysts on each slide. Cysts were considered to have germinated if the length of the germ tube was greater than the diameter of the cyst. The remaining spores in the Eppendorf tubes were assessed after $8 \mathrm{~h} ; 100$ cysts were scored for germination by germ tubes and for release of a further single zoospore. Empty cyst cases (ghosts) were counted as cysts that had released a zoospore.

Effects of calcium in fertilizer solutions on infection of vinca seedlings. Three-week-old vinca seedlings, cultivar Grape Cooler, were produced from seed sown in Redi-Earth Peat-Lite Mix (Scotts-Sierra Horticultural Products Company) in 288-plug plastic seedling trays. The trays were incubated in a growth chamber with a 12 -h light $\left(28^{\circ} \mathrm{C}\right) / 12$-h dark $\left(22^{\circ} \mathrm{C}\right)$ cycle and irrigated daily with tap water. Blocks of 12 or 16 seedlings, arranged three by four or four by four, were cut from the plastic seedling trays and

TABLE 2. Effects of different concentrations of soluble fertilizer solution (Peters 20-10-20 Peat Lite Special) on release of zoospores from sporangia ${ }^{\mathrm{a}}$

\begin{tabular}{|c|c|c|c|c|c|c|c|c|c|}
\hline & \multicolumn{7}{|c|}{ Peters concentration (ppm of nitrogen) } & \multirow[b]{2}{*}{$5 \%$ LSD } & \multirow[b]{2}{*}{$P(\mathrm{ANOVA})$} \\
\hline & 0 & 100 & 150 & 200 & 300 & 400 & 450 & & \\
\hline \multicolumn{10}{|c|}{ Discharged sporangia $^{b}$} \\
\hline Experiment 1 & 38 & 59.7 & $\ldots$ & 57.7 & 44.7 & 38.3 & $\ldots$ & 10.5 & $1.2 \times 10^{-3}$ \\
\hline Experiment 2 & 49 & $\ldots$ & 74.3 & $\ldots$ & 58.7 & $\ldots$ & 49 & 12.9 & $5.8 \times 10^{-3}$ \\
\hline \multicolumn{10}{|c|}{ Discharged cell count ${ }^{\mathrm{c}}$} \\
\hline Experiment 1 & 94.8 & 139 & $\ldots$ & 139.7 & 77.7 & 57 & $\ldots$ & 39.2 & $4.0 \times 10^{-4}$ \\
\hline Experiment 2 & 93.2 & $\ldots$ & 181.3 & $\ldots$ & 51.2 & $\ldots$ & 22.2 & 42.8 & $1.4 \times 10^{-4}$ \\
\hline
\end{tabular}

a Data from two experiments.

b Numbers of sporangia with discharged contents (means of 100 assessed in each of three replicate dishes).

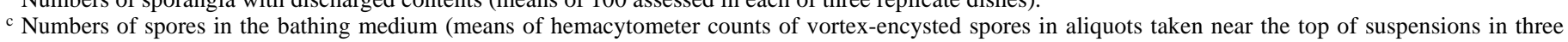
replicate dishes). 
placed in the bottoms of $100-\mathrm{mm}$-square petri dishes $24 \mathrm{~h}$ prior to inoculation. Seedling blocks were, thereafter, irrigated by adding nutrient solutions to individual dishes to simulate flood irrigation. Inoculum was prepared from zoospores released into $150 \mathrm{ppm}$ of $\mathrm{N}$ Peters PLS as previously described. The suspensions were used as either motile zoospores or vortex-encysted (70 s) spores and were diluted to approximately $10^{2}$ cells $/ \mathrm{ml}$ by addition of $150 \mathrm{ppm}$ of N Peters PLS or 150 ppm of N Peters PLS amended with 10 or $20 \mathrm{mM} \mathrm{Ca}\left(\mathrm{NO}_{3}\right)_{2}$. In a preliminary experiment, suspensions of $10^{2}, 10^{3}$, and $10^{4}$ motile cells $/ \mathrm{ml}$ were used to determine that $10^{2}$ cells $/ \mathrm{ml}$ was usually sufficient to give $>95 \%$ infection of inoculated plants.

Seedling blocks were flood-irrigated on the morning of the day of inoculation with $25 \mathrm{ml}$ of $150 \mathrm{ppm}$ of N Peters PLS with or without $\mathrm{Ca}\left(\mathrm{NO}_{3}\right)_{2}$ to ensure that the peat mix was saturated. Later that day, the seedling blocks were flooded again with $20 \mathrm{ml}$ of the corresponding solution with or without (controls) inoculum. Thereafter, seedlings were flood-irrigated daily with $25 \mathrm{ml}$ of the appropriate irrigation solution that did not contain inoculum. Symptoms and plant deaths were recorded daily. After 10 days, all seedlings were removed, washed free of peat mix, and placed on a Phytophthora-selective medium (31) to detect infection by $P$. parasitica. In some experiments, additional blocks of uninoculated plants were included to test the effects of the irrigation solutions on plant growth as measured by total dry weight. These plants were removed, washed, placed in small paper bags, ovendried $\left(72 \mathrm{~h}\right.$ at $\left.180^{\circ} \mathrm{C}\right)$, and weighed.
Experimental design and statistical analysis. All treatments were replicated three times, and all treatment effects were repeated at least twice. Results were analyzed by analysis of variance (ANOVA) and, in some cases, also by regression using Microsoft Excel version 5 (Microsoft Corp., Redmond, WA). Numbers of infected plants or plant deaths were analyzed by chisquared, using Yates' correction when there was only one degree of freedom. Percentage data were converted to arcsine values for analysis.

\section{RESULTS}

Effects of calcium in aqueous solution on zoospore release from sporangia. $\mathrm{Ca}^{2+}$ treatments affected the production of zoospores from sporangia at two different stages: during cleavage of the sporangium protoplasm into uninucleate cells and at the stage when zoospores were released by dissolution of the sporangium papillum. $\mathrm{CaCl}_{2}$ had a concentration-dependent effect on both of these processes (Table 1). The number of sporangia with cleaved contents was positively correlated with $\mathrm{CaCl}_{2}$ concentration in the range of 0 to $50 \mathrm{mM}\left(r=0.972, P=1.55 \times 10^{-9}\right)$ and was significantly enhanced by $50 \mathrm{mM} \mathrm{CaCl}{ }_{2}$ compared with the water controls (ANOVA). But discharge of zoospores from the cleaved sporangia was negatively correlated $\left(r=0.91, P=3.3 \times 10^{-6}\right)$ with $\mathrm{CaCl}_{2}$ concentration over the range 0 to $50 \mathrm{mM}$ and was significantly reduced by even $20 \mathrm{mM} \mathrm{CaCl}{ }_{2}$ (ANOVA). Therefore, the overall effect of $\mathrm{CaCl}_{2}$ was to reduce significantly the release of

TABLE 3. Effects of $\mathrm{CaCl}_{2}$ and $\mathrm{Ca}\left(\mathrm{NO}_{3}\right)_{2}$ amendments in Peters Peat Lite Special (PLS) soluble fertilizer solution (150 ppm of $\mathrm{N}$ ) on release of zoospores from sporangia $^{\mathrm{a}}$

\begin{tabular}{|c|c|c|c|c|c|c|c|c|c|c|c|c|}
\hline \multirow[b]{2}{*}{ Exp. } & \multirow[b]{2}{*}{ Assessment } & \multirow[b]{2}{*}{ Water control } & \multicolumn{8}{|c|}{ Peters PLS $150 \mathrm{ppm}$ of $\mathrm{N}+$ calcium as $\mathrm{mM} \mathrm{CaCl}{ }_{2}$ or $\mathrm{Ca}\left(\mathrm{NO}_{3}\right)_{2}$} & \multirow[b]{2}{*}{$5 \%$ LSD } & \multirow[b]{2}{*}{$\begin{array}{c}P \\
\text { (ANOVA) }\end{array}$} \\
\hline & & & $0 \mathrm{mM}$ & $\begin{array}{c}10 \mathrm{mM} \\
\mathrm{Cl}\end{array}$ & $\begin{array}{c}10 \mathrm{mM} \\
\mathrm{NO}_{3}\end{array}$ & $\begin{array}{c}20 \mathrm{mM} \\
\mathrm{Cl}\end{array}$ & $\begin{array}{c}20 \mathrm{mM} \\
\mathrm{NO}_{3}\end{array}$ & $\begin{array}{c}30 \mathrm{mM} \\
\mathrm{Cl}\end{array}$ & $\begin{array}{c}30 \mathrm{mM} \\
\mathrm{NO}_{3}\end{array}$ & $\begin{array}{c}40 \mathrm{mM} \\
\mathrm{NO}_{3}\end{array}$ & & \\
\hline 1 & Discharged sporangia $^{b}$ & $\ldots$ & 61.7 & 51.7 & 50 & 37.3 & 35 & 23.3 & 17.7 & $\ldots$ & 13.7 & $7.0 \times 10^{-5}$ \\
\hline 2 & $\begin{array}{l}\text { Discharged sporangia } \\
\text { Spore count }{ }^{\mathrm{c}}\end{array}$ & $\begin{array}{c}49 \\
135.7\end{array}$ & $\begin{array}{c}51 \\
113.2\end{array}$ & $\begin{array}{l}\cdots \\
\cdots\end{array}$ & $\begin{array}{l}31.3 \\
104\end{array}$ & $\begin{array}{l}\cdots \\
\cdots\end{array}$ & $\begin{array}{r}9.7 \\
26.5\end{array}$ & $\begin{array}{l}\cdots \\
\cdots\end{array}$ & $\begin{array}{r}3.7 \\
10.8\end{array}$ & $\begin{array}{l}3 \\
5\end{array}$ & $\begin{array}{r}9.9 \\
27.9\end{array}$ & $\begin{array}{l}1.6 \times 10^{-7} \\
8.2 \times 10^{-12}\end{array}$ \\
\hline 3 & $\begin{array}{l}\text { Discharged sporangia } \\
\text { Spore count }\end{array}$ & $\begin{array}{c}47 \\
212.7\end{array}$ & $\begin{array}{c}81 \\
143.7\end{array}$ & $\begin{array}{l}\ldots \\
\cdots\end{array}$ & $\begin{array}{r}65 \\
127\end{array}$ & $\begin{array}{l}\cdots \\
\cdots\end{array}$ & $\begin{array}{r}40 \\
127\end{array}$ & $\begin{array}{l}\cdots \\
\cdots\end{array}$ & $\begin{array}{l}15 \\
15\end{array}$ & $\begin{array}{l}6.3 \\
4\end{array}$ & $\begin{array}{l}16.4 \\
55.4\end{array}$ & $\begin{array}{l}8.6 \times 10^{-7} \\
1.9 \times 10^{-5}\end{array}$ \\
\hline
\end{tabular}

${ }^{a}$ Data from three experiments.

${ }^{\mathrm{b}}$ Numbers of sporangia (means of 100 assessed in each of three replicate dishes) that had discharged their contents as zoospores.

${ }^{c}$ Numbers of spores in the bathing medium (means of hemacytometer counts of vortex-encysted spores in aliquots taken near the top of suspensions in three replicate dishes).

TABLE 4. Effects of $\mathrm{Ca}\left(\mathrm{NO}_{3}\right)_{2}$ amendments in Peters Peat Lite Special (PLS) soluble fertilizer solution (150 ppm of N) on zoospore motility

\begin{tabular}{lccccccc}
\hline & & \multicolumn{5}{c}{ Ca level (meq) in Peters PLS solution } \\
\cline { 3 - 7 } & Water control & 0 & 10 & 20 & 30 & 40 & 5\% LSD \\
\hline Motile spore count $^{\mathrm{a}}$ & 194.3 & 205.7 & 59.7 & 9.3 & 0 & 0 & 84.3 \\
Motile as percent of total $^{\mathrm{b}}$ & 89.4 & 84.0 & 27.8 & 1.4 & 0 & 0 & $3.4 \times 10^{-2}$ \\
\hline
\end{tabular}

a Means of three replicate dishes, based on in situ counts of spores $2 \mathrm{~h}$ after chill induction of zoospore release; three random microscope fields were used for each dish, and the data were recorded as the sum of spores near the top and at the bottom of the suspension in each microscope field.

${ }^{\mathrm{b}}$ Calculated from the grand means (of three dishes) of motile and total cells; $86 \%$ of all motile spores were found at the top of the spore suspensions.

TABLE 5. Numbers of motile zoospores 1 to $4 \mathrm{~h}$ after their release into Peters Peat Lite Special fertilizer solution (150 ppm of N) with or without $20 \mathrm{mM}$ $\mathrm{Ca}\left(\mathrm{NO}_{3}\right)_{2}$

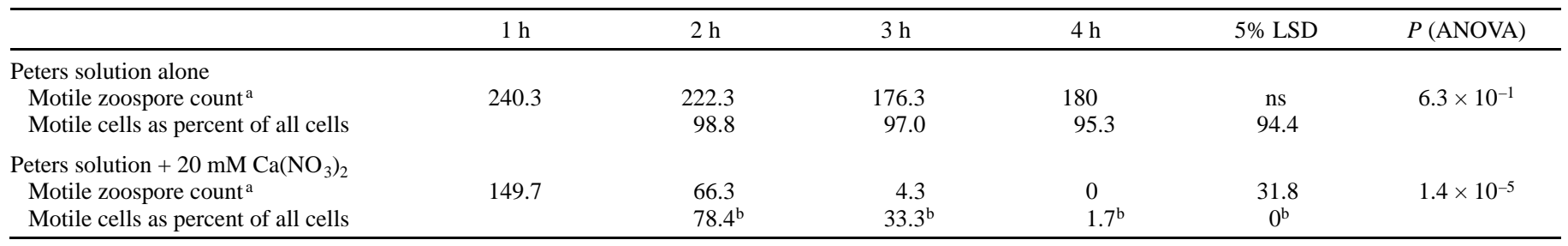

a Means of three replicate dishes, based on counts in three random microscope fields per dish. Two-way analysis of variance showed significant effects of presence/absence of $\mathrm{Ca}^{2+}\left(P=2.27 \times 10^{-6}\right)$ and time $\left(P=7.0 \times 10^{-3}\right)$, but no significant $\mathrm{Ca}^{2+} /$ time interaction $(P=0.44)$.

${ }^{\mathrm{b}}$ Significantly less than in Peters solution alone $(P<0.0032)$, by $t$ test of arcsine-transformed percentages. 
infective propagules, even though $\mathrm{CaCl}_{2}$ enhanced differentiation in the sporangia.

Effects of Peters PLS solution on zoospore release from sporangia. In the absence of calcium, Peters PLS solution at 100 to $200 \mathrm{ppm}$ of $\mathrm{N}$ enhanced the number of discharged sporangia and also the number of spores assessed in the bathing solutions compared with water controls (Table 2). Higher concentrations of Peters PLS solution ( 300 to $450 \mathrm{ppm}$ of $\mathrm{N}$ ) neither enhanced nor suppressed sporangium discharge compared with the water controls. However, the number of spores assessed in aliquots of the bathing solutions was reduced by high concentrations of Peters PLS (Table 2). This effect was explained by assessment of zoospore motility from videotapes in the second experiment in Table 2 . Based on counts of at least 150 cells in each dish after $2 \mathrm{~h}$, the percentage of motile spores was 59,91, 81, and 59 for the 0,150 , 300 , and $450 \mathrm{ppm}$ of $\mathrm{N}$ treatments, respectively. All the motile cells in the 450-ppm treatment were near the bottom of the dishes and were swimming slowly and erratically. In the other solutions, the motile spores were swimming normally, near the top of the suspensions where samples had been taken for the tabulated cell counts.

Effects of calcium in Peters PLS solution on zoospore release from sporangia. In each of three experiments (Table 3), amendment of Peters PLS solution (150 ppm of $\mathrm{N}$ ) with calcium reduced sporangial discharge progressively over the range of 0 to 40 meq of $\mathrm{Ca}^{2+}$. This was reflected in both the numbers of discharged sporangia and the numbers of spores assessed in the release solutions. $\mathrm{CaCl}_{2}$ and $\mathrm{Ca}\left(\mathrm{NO}_{3}\right)_{2}$ were equally effective, indicating that the effect was caused by the $\mathrm{Ca}^{2+}$ ion. The concentrations of 30 and 40 meq of $\mathrm{Ca}^{2+}$ were highly suppressive, but significant reductions compared with Peters PLS solution alone were obtained at even 10 or 20 meq of $\mathrm{Ca}^{2+}$.

Effects of calcium on zoospore motility in fertilizer solution. Motility was assessed for spores released from sporangia into solutions of different calcium content. In the absence of $\mathrm{Ca}^{2+}$, most zoospores remained motile for at least $3 \mathrm{~h}$ in Peters PLS solution (150 ppm of N). Only $16 \%$ of the zoospores had encysted at this time (Table 4), and the cysts had deposited to the bottom of the suspensions, whereas most of the motile spores remained near

TABLE 6. Effects of aqueous solutions of $\mathrm{CaCl}_{2}$ on percentage of germination of zoospore cysts by germ tubes and on release of a further zoospore from nongerminated cysts ${ }^{\mathrm{a}}$

\begin{tabular}{lccccc}
\hline & \multicolumn{3}{l}{$\mathrm{CaCl}_{2}$ concentration $(\mathrm{mM})$} & & \\
\cline { 2 - 4 } Mode of germination & 0 & 10 & 20 & 5\% LSD & $P$ (ANOVA) \\
\hline Germ tube & 18.3 & 39.7 & 51.7 & 16.6 & $7.4 \times 10^{-3}$ \\
Zoospore release & 42.7 & 7.3 & 7 & 12.3 & $5.5 \times 10^{-4}$ \\
Total & 61 & 47 & 58.7 & $\mathrm{~ns}$ & $7.2 \times 10^{-2}$ \\
\hline
\end{tabular}

${ }^{\text {a }}$ Means of assessment of 100 cysts in each of three replicates assessed 7 to 8 $\mathrm{h}$ after vortex-encystment of zoospores released into the different solutions. the liquid surface. These findings were similar to those for spores in the water controls. The presence of even $10 \mathrm{mM} \mathrm{Ca}\left(\mathrm{NO}_{3}\right)_{2}$ in Peters PLS solution (150 ppm of $\mathrm{N}$ ) significantly reduced the number of motile zoospores after $3 \mathrm{~h}$; most of the spores had encysted. At $20 \mathrm{mM} \mathrm{Ca}^{2+}$, there were few motile spores and, at the higher $\mathrm{Ca}^{2+}$ concentrations, there were few spores to assess (and none motile), because the release of spores from sporangia had been strongly suppressed.

In a further experiment (Table 5), the sporangia were removed from the spore suspensions after $1 \mathrm{~h}$ so that no further zoospores would be released, and motility of the spores was assessed periodically. In Peters PLS solution alone (150 ppm of N), there was no significant reduction in motility during the first $4 \mathrm{~h}$. Amendment of Peters PLS solution with $20 \mathrm{mM} \mathrm{Ca}\left(\mathrm{NO}_{3}\right)_{2}$ caused a small, significant reduction in motility during the first hour and major reductions after 2 and $3 \mathrm{~h}$. Again, the motile spores were found mainly near the surface of the suspensions, whereas most cysts were found at the bottom of the dishes.

Effects of soluble fertilizer solutions and calcium on cyst germination. Zoospores that had been encysted by vortex treatment after release into the different solutions either germinated within $2 \mathrm{~h}$ by producing a germ tube, or the cysts remained quiescent for 5 to $6 \mathrm{~h}$ and then released a further single zoospore from a short protuberance. The numbers of cells that responded in these ways were assessed after 7 to $8 \mathrm{~h}$, because the data for germ tube production at that time interval did not differ significantly from the data at $2 \mathrm{~h}$ in initial experiments.

The presence of 10 or $20 \mathrm{mM} \mathrm{CaCl} 2$ in aqueous solution significantly increased the germination by germ tubes, but markedly suppressed the release of further zoospores from the same population of cysts (Table 6). In the absence of $\mathrm{Ca}^{2+}$, Peters PLS fertilizer solution had a significant concentration-dependent effect on germination in each of two experiments (Table 7). Germination by germ tubes was enhanced by increasing concentrations of Peters PLS solution, but the lowest concentration (100 ppm of N) had no significant effect compared with the water controls. Conversely, Peters PLS solution caused a concentration-dependent suppression of zoospore release from ungerminated cysts, and even the low concentrations ( 100 or $200 \mathrm{ppm}$ of $\mathrm{N}$ ) significantly suppressed the release of further zoospores. The same patterns of response to treatments were seen in two experiments, even though the overall level of germination by germ tubes differed between these experiments (Table 7). The presence of either $\mathrm{CaCl}_{2}$ or $\mathrm{Ca}\left(\mathrm{NO}_{3}\right)_{2}$ in Peters PLS solution (150 ppm of $\mathrm{N}$ ) enhanced germination by germ tubes (significant for $20 \mathrm{meq}$ of $\mathrm{Ca}^{2+}$ ) and suppressed the release of a further zoospore from cysts (significant for both 10 and 20 meq of $\mathrm{Ca}^{2+}$ ) (Table 8).

Effects of calcium on infection of vinca seedlings. In an initial experiment with blocks of 12 seedlings, flood inoculation of vinca with $10^{2}, 10^{3}$, or $10^{4}$ zoospores $/ \mathrm{ml}$ of Peters PLS solution (150 ppm of $\mathrm{N}$ ) caused infection of all (36) or nearly all (35 of a

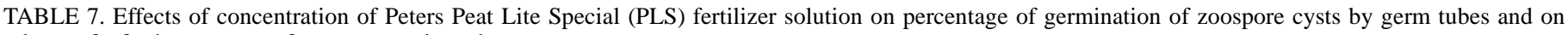
release of a further zoospore from nongerminated cysts ${ }^{\mathrm{a}}$

\begin{tabular}{|c|c|c|c|c|c|c|c|}
\hline \multirow{2}{*}{$\begin{array}{l}\text { Experiment and } \\
\text { mode of germination }\end{array}$} & \multicolumn{5}{|c|}{ Peters PLS concentration (ppm of $\mathrm{N}$ ) } & \multirow[b]{2}{*}{$5 \%$ LSD } & \multirow[b]{2}{*}{$P$ (ANOVA) } \\
\hline & 0 & 100 & 200 & 300 & 400 & & \\
\hline \multicolumn{8}{|l|}{ Experiment 1} \\
\hline Germ tube & 34 & 35 & $\ldots$ & 83.7 & $\ldots$ & 20.2 & $1.4 \times 10^{-3}$ \\
\hline Zoospore & 46.7 & 18.3 & $\ldots$ & 1.3 & $\ldots$ & 15.8 & $1.2 \times 10^{-3}$ \\
\hline Total & 80.7 & 53.3 & $\ldots$ & 85 & $\ldots$ & 11.8 & $1.2 \times 10^{-3}$ \\
\hline \multicolumn{8}{|l|}{ Experiment 2} \\
\hline Germ tube & 11.3 & 10.3 & 22 & 30.7 & 32 & $\mathrm{~ns}^{\mathrm{b}}$ & $6.7 \times 10^{-1}$ \\
\hline Zoospore & 62.5 & 40 & 14.5 & 24.5 & 21.5 & 29.44 & $4.4 \times 10^{-2}$ \\
\hline
\end{tabular}

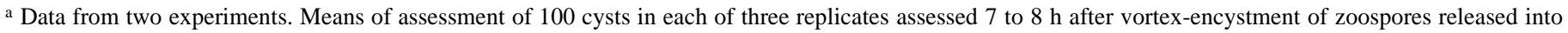
the different solutions.

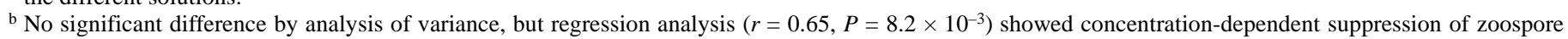
release. 
total 36) seedlings assessed by reisolation of the pathogen from the roots. The cumulative plant deaths over 10 days were 13, 23, and 23, respectively, for the three inoculum levels. As an additional treatment, $20 \mathrm{mM} \mathrm{Ca}\left(\mathrm{NO}_{3}\right)_{2}$ was used in Peters PLS solution containing $10^{2}$ zoospores $/ \mathrm{ml}$. Only two of a total 36 seedlings were infected, and none of them died. The effect of $\mathrm{Ca}^{2+}$ in suppressing infection from $10^{2}$ zoospores/ml was highly significant $\left(\chi^{2}=28.66, P<0.001\right)$.

A second experiment with blocks of 16 seedlings and $10^{2}$ zoospores/ml (not shown) confirmed the suppressive effect of calcium: 22 of a total 48 seedlings were infected (12 deaths) when flood-irrigated with Peters PLS solution (150 ppm of N), but only four of a total 48 seedlings were infected (two deaths) when the Peters PLS solution was amended with $20 \mathrm{mM} \mathrm{Ca}\left(\mathrm{NO}_{3}\right)_{2}$. The suppression of infection by calcium was highly significant $\left(\chi^{2}=11.11, P<0.001\right)$.

In two further experiments (Table 9), the zoospores $\left(10^{2} / \mathrm{ml}\right)$ were either motile or pre-encysted by vortex treatment. In Peters PLS solution (150 ppm of $\mathrm{N})$ alone, the seedlings were infected from both motile and encysted spores, but amendment of Peters PLS solution with $20 \mathrm{mM} \mathrm{Ca}\left(\mathrm{NO}_{3}\right)_{2}$ almost completely suppressed infection from motile spores $\left(P<0.001\right.$ by $\chi^{2}$ in each experiment) and reduced infection from pre-encysted spores. Even $10 \mathrm{mM} \mathrm{Ca}\left(\mathrm{NO}_{3}\right)_{2}$ was suppressive in the one experiment in which it was used. None of the 324 uninoculated control seedlings in the four experiments became infected. There was no significant difference in plant dry weight between uninoculated controls irrigated with Peters PLS solution (150 ppm of $\mathrm{N}$ ) alone or containing $20 \mathrm{mM} \mathrm{Ca}\left(\mathrm{NO}_{3}\right)_{2}$ (mean dry weights, 43.1 and $42.0 \mathrm{mg}$, respectively; $P=0.71$ ).

\section{DISCUSSION}

The 16 representative experiments reported here show that $\mathrm{Ca}^{2+}$ amendments in the range of 10 to $30 \mathrm{meq}$ in either water or Peters PLS fertilizer solution significantly affect several stages of the production and behavior of $P$. parasitica zoospores. The effects of $\mathrm{Ca}^{2+}$ on the different stages were analyzed separately, but they were cumulative, so manipulation of $\mathrm{Ca}^{2+}$ has the potential to reduce markedly the availability of inoculum for primary infection and secondary spread of infection by $P$. parasitica in irrigation systems. This was confirmed by the dramatic reduction of infec- tion of vinca seedlings when even low levels of $\mathrm{Ca}^{2+}$ were added to fertilizer solution in a simulated flood irrigation system. The effects of other cations were not tested in this study, but the findings for $\mathrm{Ca}^{2+}$ are important because they demonstrate that this ion, which is essential for normal zoospore behavior $(6,8,9,13,14,32)$, can profoundly interfere with zoospore biology when supplied at supra-optimal levels for the fungus.

Calcium salts in the range of 10 to $40 \mathrm{mM}$ had a concentrationdependent effect in reducing the release of zoospores from sporangia. Yet $\mathrm{Ca}^{2+}$ did not visibly suppress the cleavage of sporangial contents - a necessary prelude to zoospore release — and high $\mathrm{Ca}^{2+}$ concentrations even enhanced sporangial cleavage. Thus, high $\mathrm{Ca}^{2+}$ levels might have interfered with the later stages of zoospore differentiation in sporangia or with the process of zoospore release that occurs by dissolution of the sporangial papillum (15). In any case, this suppressive effect of $\mathrm{Ca}^{2+}$ on release from sporangia was paralleled by suppression of release of a further zoospore from zoospore cysts.

The higher concentrations of Peters PLS fertilizer solution (300, 400 , and $450 \mathrm{ppm}$ of $\mathrm{N}$ ) also suppressed zoospore discharge from sporangia, but the fertilizer concentrations more commonly used for containerized ornamental crops (100 to $200 \mathrm{ppm}$ of $\mathrm{N}$ ) either had no effect on zoospore discharge or enhanced it compared with that of water controls. This stimulatory effect of low salt concentrations on release of zoospores from sporangia is commonly reported $(12,14)$. It was negated by the addition of 10 or 20 meq of $\mathrm{Ca}^{2+}$ to Peters PLS solution (150 ppm of N), suggesting that calcium amendment of either irrigation water or commercial nutrient solution should reduce the production of secondary inoculum from primary infections of plants.

In addition to suppression of zoospore production, $\mathrm{Ca}^{2+}$ concentrations of 20 meq or more curtailed the motility of zoospores in a commercial fertilizer solution, causing them to encyst. This effect of $\mathrm{Ca}^{2+}$ on zoospore encystment is also reported for P. cinnamomi (2). $\mathrm{Ca}^{2+}$ amendment, therefore, should diminish the role of zoospores in locating the preferred infection sites on roots $(6,35)$ and reduce the autonomous movement or passive transport of zoospores through particulate materials $(24,33)$ or root mats (16). Furthermore, the curtailment of zoospore motility would influence the distribution of inoculum in irrigation systems, be-

TABLE 8. Effects of $\mathrm{CaCl}_{2}$ or $\mathrm{Ca}\left(\mathrm{NO}_{3}\right)_{2}$ in Peters Peat Lite Special fertilizer solution (150 ppm of $\mathrm{N}$ ) on percentage of germination of zoospore cysts by germ tubes and on release of a further zoospore from nongerminated cysts ${ }^{\mathrm{a}}$

\begin{tabular}{|c|c|c|c|c|c|c|c|}
\hline \multirow[b]{2}{*}{ Mode of germination } & \multicolumn{5}{|c|}{ Concentration $(\mathrm{mM})$ of $\mathrm{CaCl}_{2}$ or $\mathrm{Ca}\left(\mathrm{NO}_{3}\right)_{2}$} & \multirow[b]{2}{*}{$5 \%$ LSD } & \multirow[b]{2}{*}{$P($ ANOVA $)$} \\
\hline & 0 & $10 \mathrm{Cl}$ & $10 \mathrm{NO}_{3}$ & $20 \mathrm{Cl}$ & $20 \mathrm{NO}_{3}$ & & \\
\hline Germ tube & 18.0 & 30.0 & 32.67 & 41.33 & 62.67 & 19.11 & $4.6 \times 10^{-3}$ \\
\hline Zoospore & 28.0 & 7.67 & 6.67 & 3.0 & 1.67 & 5.09 & $2.6 \times 10^{-6}$ \\
\hline
\end{tabular}

${ }^{a}$ Means of assessment of 100 cysts in each of three replicates assessed 7 to $8 \mathrm{~h}$ after vortex-encystment of zoospores released into the different solutions.

TABLE 9. Numbers of vinca seedlings infected (and plant deaths in parentheses) 10 days after blocks of 16 seedlings were flood-irrigated with Peters Peat Lite Special fertilizer solution ( $150 \mathrm{ppm}$ of $\mathrm{N}$ ), with or without $\mathrm{Ca}\left(\mathrm{NO}_{3}\right)_{2}$, and containing either motile zoospores or vortex-encysted zoospores $\left(10^{2}\right.$ cells/ml)

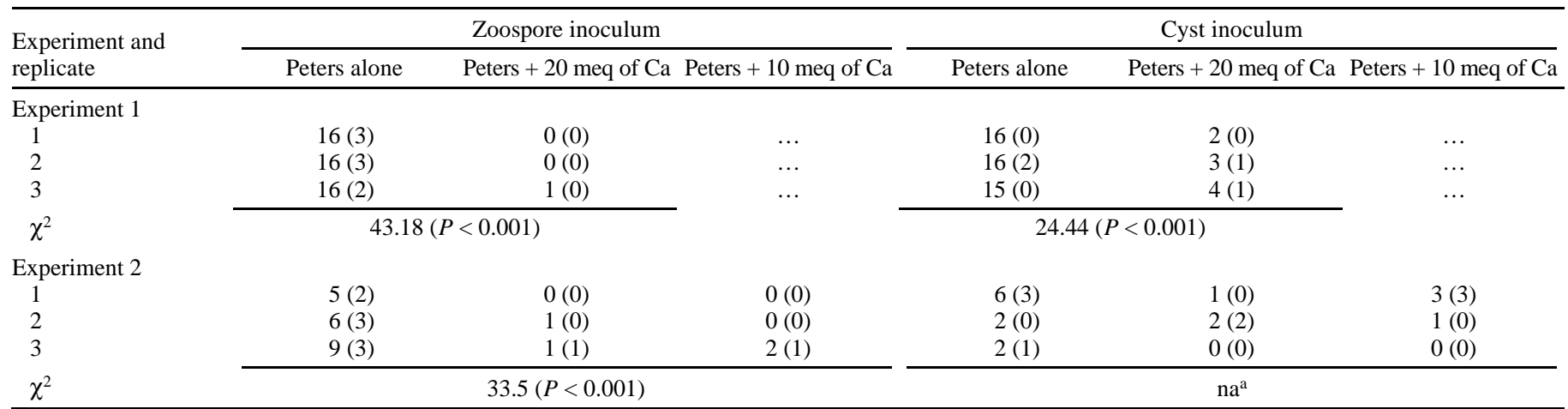

${ }^{a}$ Not applicable; insufficient counts for $\chi^{2}$ analysis. 
cause zoospores of Phytophthora spp. swim towards the surface of a liquid $(3,4)$, whereas cysts settle out of suspension, as confirmed here for $P$. parasitica. This might be exploited in the design of recirculating systems.

High levels of $\mathrm{Ca}^{2+}$ applied soon after encystment can trigger the production of germ tubes from zoospore cysts of $P$. cinnamomi (2), P. parasitica (32), Pythium spp. (8), and Aphanomyces spp. (5). For $P$. cinnamomi, this effect was unique to $\mathrm{Ca}^{2+}$ among all the cations tested (2), but for Pythium, the effect of $\mathrm{Ca}^{2+}$ could be mimicked by $\mathrm{Mg}^{2+}$ or $\mathrm{Sr}^{2+}$, which act as surrogates for $\mathrm{Ca}^{2+}$ in several physiological processes (8). Previously, we reported that $\mathrm{Ca}^{2+}$ applied post-encystment could markedly suppress the release of a further zoospore from cysts of $P$. parasitica that had not produced germ tubes (32). Here we show the same effects of $\mathrm{Ca}^{2+}$ on cysts derived from zoospores that were released initially into solutions of different calcium content. The production of a germ tube in the absence of a host or organic nutrients would lead to energy depletion of the propagules (21). The suppression of further zoospore release from ungerminated cysts would ensure that these propagules do not contribute to further infection.

As a test of the practical relevance of these findings, $\mathrm{Ca}^{2+}$ at 20 meq was shown significantly and markedly to reduce infection of containerized vinca seedlings from zoospores in a flood-irrigated system employing Peters PLS fertilizer solution. The effect was consistent in each of four experiments. Even $10 \mathrm{meq}$ of $\mathrm{Ca}^{2+}$ was effective in the one experiment in which it was tested, and $20 \mathrm{meq}$ of $\mathrm{Ca}^{2+}$ also significantly reduced infection from encysted zoospore inoculum. The design of these experiments ensured that relatively high levels of viable inoculum were introduced into the bases of plugs of peat containing susceptible seedlings, and the criterion for infection was reisolation of the pathogen from any part of a seedling root system. Thus, these were rigorous tests of the effectiveness of $\mathrm{Ca}^{2+}$ in suppressing infection in a simulated ebb and flow irrigation system. Moreover, the tests employed a standard inoculum concentration across treatments, so they did not take account of any additional suppressive effect of $\mathrm{Ca}^{2+}$ on zoospore release from sporangia.

Peters PLS contains no calcium so that it can be used in water from sources that differ in water quality. The calcium levels in water used for ornamentals are usually much lower than 20 meq; typically the $\mathrm{Ca}^{2+}$ level is less that $2 \mathrm{meq}$, although $7 \mathrm{meq}$ is not uncommon for hydroponically grown vegetables in which $\mathrm{Ca}\left(\mathrm{NO}_{3}\right)_{2}$ is used as a nitrogen source. In short term experiments, we found no adverse effect of $\mathrm{Ca}^{2+}$ on growth of vinca seedlings at the $\mathrm{Ca}^{2+}$ levels effective for disease control. But high $\mathrm{Ca}^{2+}$ levels could affect plants if applied continuously, especially for plants grown in peat mixes, which accumulate salts with time $(7,34)$. This accumulation, however, could be an advantage in reducing the total amount of $\mathrm{Ca}^{2+}$ applied, or the time over which it needs to be applied. Currently, no fungicides are registered for application through irrigation water; surfactants also are not registered for use in disease control. Fungicides can be applied as drenches to ornamentals in containerized media, but with the risk that pathogens could develop fungicide resistance during constant exposure to low doses.

Manipulation of calcium levels with multifactorial and cumulative effects on zoospore inoculum could be part of a disease management strategy for calcium-tolerant crops. It is relevant to infection in recirculating irrigation systems, in peat-based media, and probably also in soil. Indeed, some of the modes of action of $\mathrm{Ca}^{2+}$ on $P$. parasitica, demonstrated here, could help to explain the many reports of calcium-mediated suppression of disease caused by Phytophthora and other zoosporic fungi.

\section{LITERATURE CITED}

1. Broadbent, P., and Baker, K. F. 1974. Behaviour of Phytophthora cinnamomi in soils suppressive and conducive to root rot. Aust. J. Agric. Res. 25:121-137.
2. Byrt, P. N., Irving, H. R., and Grant, B. R. 1982. The effect of cations on zoospores of the fungus Phytophthora cinnamomi. J. Gen. Microbiol. 128:1189-1198.

3. Cameron, J. N., and Carlile, M. J. 1977. Negative geotaxis of zoospores of the fungus Phytophthora. J. Gen. Microbiol. 98:599-602.

4. Carlile, M. J. 1983. Motility, taxis and tropism in Phytophthora. Pages 95-107 in: Phytophthora. Its Biology, Taxonomy, Ecology and Pathology. D. C. Erwin, S. Bartnicki-Garcia, and P. H. Tsao, eds. The American Phytopathological Society, St. Paul, MN.

5. Cerenius, L., and Söderhall, K. 1985. Repeated zoospore emergence as a possible adaptation to parasitism in Aphanomyces. Exp. Mycol. 9:259263.

6. Deacon, J. W., and Donaldson, S. P. 1993. Molecular recognition in the homing responses of zoosporic fungi, with special reference to Pythium and Phytophthora. Mycol. Res. 97:1153-1171.

7. Dole, J. M., Cole, J. C., and von Broembsen, S. L. 1994. Growth of poinsettias, nutrient leaching, and water-use efficiency respond to irrigation methods. HortScience 29:858-864.

8. Donaldson, S. P., and Deacon, J. W. 1992. Role of calcium in adhesion and germination of zoospore cysts of Pythium: A model to explain infection of host plants. J. Gen. Microbiol. 138:2051-2059.

9. Donaldson, S. P., and Deacon, J. W. 1993. Changes in motility of Pythium zoospores induced by calcium and calcium-modulating drugs. Mycol. Res. 97:877-883.

10. Duniway, J. M., and Gordon, T. R. 1986. Water relations and pathogen activity in soil. Pages 119-137 in: Water, Fungi and Plants. P. G. Ayres and L. Boddy, eds. Cambridge University Press, Cambridge.

11. Gilbert, G. S., Handelsman, J., and Parke, J. L. 1990. Role of ammonia and calcium in lysis of zoospores of Phytophthora cactorum by Bacillus cereus strain UW85. Exp. Mycol. 14:1-8.

12. Gooding, G. V., and Lucas, G. B. 1959. Factors influencing sporangial formation and zoospore activity in Phytophthora parasitica var. nicotianae. Phytopathology 49:277-281.

13. Gubler, F., Hardham, A. R., and Duniec, J. 1989. Characterizing adhesiveness of Phytophthora cinnamomi zoospores during encystment. Protoplasma 149:24-30.

14. Halsall, D. M., and Forrester, R. I. 1977. Effects of certain cations on the formation and infectivity of Phytophthora zoospores. I. Effect of calcium, magnesium, potassium and iron ions. Can. J. Microbiol. 23:9941001.

15. Ho, H. H., and Hickman, C. J. 1967. Asexual reproduction and behavior of zoospores of Phytophthora megasperma var. sojae. Can. J. Bot. 45:1963-1981.

16. Holderness, M., and Pegg, G. F. 1986. Interaction of host stress and pathogen ecology on Phytophthora infection and symptom expression in nutrient film-grown tomatoes. Pages 189-205 in: Water, Fungi and Plants. P. G. Ayres and L. Boddy, eds. Cambridge University Press, Cambridge.

17. Huber, D. M., and Watson, R. D. 1970. Effect of organic amendment on soil-borne plant pathogens. Phytopathology 60:22-26.

18. Jones, S. W., Donaldson, S. P., and Deacon, J. W. 1991. Behaviour of zoospores and zoospore cysts in relation to root infection by Pythium aphanidermatum. New Phytol. 117:289-301.

19. Kao, C. W., and Ko, W. H. 1986. The role of calcium and microorganisms in suppression of cucumber damping-off caused by Pythium splendens in a Hawaiian soil. Phytopathology 76:221-225.

20. Lin, Y. S., Sun, S. K., Hsu, S. T., and Hsieh, W. H. 1990. Mechanisms involved in the control of soil-borne plant pathogens by S-H mixture. Pages 249-259 in: Biological Control of Soil-borne Plant Pathogens. D. Hornby, ed. C.A.B. International, Wallingford, United Kingdom.

21. Lockwood, J. L. 1990. Relation of energy stress to behaviour of soilborne plant pathogens and to disease development. Pages 197-214 in: Biological Control of Soil-borne Plant Pathogens. D. Hornby, ed. C.A.B. International, Wallingford, United Kingdom.

22. Morris, B. M., Reid, B., and Gow, N. A. R. 1992. Electrotaxis of zoospores of Phytophthora palmivora at physiologically relevant field strengths. Plant Cell Environ. 15:345-353.

23. Neher, D., and Duniway, J. M. 1992. Dispersal of Phytophthora parasitica in tomato fields by furrow irrigation. Plant Dis. 76:582-586.

24. Newhook, F. J., Young, B. R., Allen, S. D., and Allen, R. N. 1981. Zoospore motility of Phytophthora cinnamomi in particulate substrates. Phytopathol. Z. 101:202-209.

25. Pegg, K. G. 1977. Biological control of Phytophthora cinnamomi root rot of avocado and pineapple in Queensland. Aust. Nurs. Assoc. Annu. Conf. Semin. Pap. 1977:7-12.

26. Reid, B., Morris, B. M., and Gow, N. A. R. 1995. Calcium-dependent, genus-specific, autoaggregation of zoospores of phytopathogenic fungi. Exp. Mycol. 19:202-213.

27. Stanghellini, M. E., Kim, D. H., Rasmussen, S. L., and Rorabaugh, P. A. 
1996. Control of root rot of peppers caused by Phytophthora capsici with a nonionic surfactant. Plant Dis. 80:1113-1116.

28. Stanghellini, M. E., Rasmussen, S. L., Kim, D. H., and Rorabaugh, P. A. 1996. Efficacy of nonionic surfactants in the control of zoospore spread of Pythium aphanidermatum in a recirculating hydroponic system. Plant Dis. 80:422-428.

29. Thingaard, K., and Andersen, H. 1995. Influence of watering frequency and electrical conductivity of the nutrient solution on Phytophthora root rot in pot plants of Gerbera. Plant Dis. 79:259-263.

30. Troutman, J. L., and Wills, W. H. 1964. Electrotaxis of Phytophthora parasitica zoospores and its possible role in infection of tobacco by the fungus. Phytopathology 54:225-228.

31. Tsao, P. H., and Ocana, G. 1969. Selective isolation of species of Phytophthora from natural soils on an improved antibiotic medium. Nature 223:636-638.
32. von Broembsen, S. L., and Deacon, J. W. 1996. Effects of calcium on germination and further zoospore release from zoospore cysts of Phytophthora parasitica. Mycol. Res. 100:1498-1504.

33. Wilkinson, H. T., Miller, R. D., and Millar, R. L. 1981. Infiltration of fungal and bacterial propagules into soil. Soil Sci. Soc. Am. J. 45:1034-1039.

34. Yelanich, M. V., and Bierbaum, J. A. 1990. Effect of fertilizer concentration and method of application on media nutrient concentration, nitrogen runoff and growth of Euphorbia pulcherrima 'V-14 Glory'. Acta Hortic. 272:185-189.

35. Zentmyer, G. A. 1961. Chemotaxis of zoospores for root exudates. Science 133:1595-1596.

36. Zhou, T., and Paulitz, T. C. 1993. In vitro and in vivo effects of Pseudomonas spp. on Pythium aphanidermatum: Zoospore behavior in exudates and on the rhizoplane of bacteria-treated cucumber roots. Phytopathology 83:872-876. 